\title{
PENGARUH p-HIDROKSI m-METOKSI KALKON (pHmMK) TERHADAP EKSPRESI PROTEIN Bel-2 dan Bax PADA SEL KANKER PAYUDARA MCF-7
}

\section{(THE EFFECT OF p-HIDROXY m-METHOXY CHALCONE (pHMMK) ON Bcl-2 AND Bax PROTEIN EXPRESSION IN MCF-7 BREAST CANCER CELL LINES)}

\author{
Retno Arianingrum $^{1)}$, Retno Sunarminingsih ${ }^{2)}$, Edy Meiyanto ${ }^{2)}$, dan Sofia Mubarika ${ }^{3)}$ \\ ${ }^{1}$ Fakultas Matematika dan Ilmu Pengetahaun Alam, Universitas Negeri Yogyakarta \\ ${ }^{2}$ Fakultas Farmasi, Universitas Gadjah Mada \\ ${ }^{3}$ Fakultas Kedokteran, Universitas Gadjah Mada \\ e-mail: Arianingrum_uny@yahoo.com
}

\begin{abstract}
Abstrak
Senyawa derivat kalkon yaitu 3-(4'-hidroksi-3'-metoksifenil)-1-fenil-2-propen1-on) atau para hidroksi meta metoksi kalkon ( $\mathrm{pHmMK}$ ) telah diteliti mampu memacu apoptosis (kematian sel) pada sel kanker payudara MCF-7. Penelitian ini bertujuan untuk mempelajari jalur mekanisme apoptosis senyawa $\mathrm{pHmMK}$ pada sel kanker MCF-7 dengan mengamati pengaruhnya terhadap ekspresi protein Bcl-2 dan Bax. Pengamatan ekspresi protein dilakukan dengan metode imunositokimia (ICC) dan dianalisis menggunakan software ImageJ. Hasil penelitian menunjukkan bahwa pemacuan apoptosis oleh $\mathrm{pHmMK}$ terjadi melalui mekanisme penurunan ekspresi Bcl-2 dan peningkatan ekspresi Bax.
\end{abstract}

Kata kunci: 3-(4'-hidroksi-3'-metoksifenil)-1-fenil-2-propen-1-on) atau para hidroksi meta metoksi kalkon ( $p \mathrm{H} m \mathrm{MK}), \mathrm{Bcl}-2$ dan Bax

\begin{abstract}
Chalcone derivate compound [3-(4'-hydroxy-3'-methoxyphenyl) -1-phenyl-2propene-1-on)] or para hydroxyl meta methoxy chalcone ( $\mathrm{HHMC}$ ) has been observed. It showed that it is able to induce apoptosis (cell death) in MCF-7 breast cancer cell. This study was aimed at finding out the apoptosis mechanism pathway of pHmMC on MCF-7 cells by observing its effect on Bcl-2 and Bax proteins. The protein expression was observed by using immunocytochemistry (ICC) and analyzed using ImageJ software. The results showed that the pHmMC induce apoptosis through mechanism that decrease expression of Bcl-2 and increase expresion of Bax proteins.
\end{abstract}

Keywords: [3- (4'-hydroxy-3'-methoxyphenyl) -1-phenyl-2-propene-1-on)] or para hydroxyl meta methoxy chalcone (pHmMC), Bcl-2 and Bax 


\section{PENDAHULUAN}

Kanker payudara termasuk dalam kelompok lima kanker penyebab kematian terbanyak, selain kanker paru-paru, liver, usus, dan kolon (WHO, 2006). Di Indonesia, pravalensi kanker payudara menduduki peringkat ke-2 setelah kanker leher rahim dan merupakan penyebab kematian utama pada wanita. Pada tahun 1991, dari semua kasus kanker pada wanita Indonesia, kasus kanker payudara mencapai $17,77 \%$ (Tjindarbumi \& Mangunkusumo, 2002).

Beberapa metode untuk pengobatan kanker telah dilakukan, di antaranya pembedahan, kemoterapi dan penyinaran (radiasi). Namun, masing-masing metode mempunyai kelemahan, sehingga tingkat keberhasilannya masih rendah (King, 2000).

Kegagalan yang sering terjadi pada pengobatan melalui kemoterapi disebabkan karena rendahnya selektivitas obat anti kanker dan adanya fenomena resistensi sel kanker terhadap agen kemoterapi (drugresistence) (Wong et al., 2006). Kasus resistensi banyak ditemukan terhadap obat anti kanker payudara, kolon, prostat dan leukemia (Davis et al., 2003). Oleh karena itu, pengembangan dan penemuan pengobatan kanker yang spesifik, khususnya kanker payudara perlu terus diupayakan.

Kalkon (1,3-difenilpropen-1-on) adalah jenis keton dengan ikatan tidak jenuh $a, b$ yang telah banyak diteliti sebagai senyawa terapetika, khususnya sebagai obat antitumor. Oleh karena aktivitasnya sebagai "high therapeutic index", kalkon pada saat itu dianggap sebagai "the new era of medicines" dalam kapasitasnya sebagai antitumor, antibakterial, dan anti-inflamatory (Shah et al., 2008). Disebutkan pula bahwa sebagian besar target utama dari senyawa-senyawa kalkon adalah mempengaruhi daur sel (Boumendjel, Ronot, \& Boutonnat, 2009).

Shen, Chang, Hsu, \& Kuo (2007) telah membuktikan bahwa struktur dasar kalkon (1,3-difenilpropen-1-on) menghambat aktivasi nuclear factor kappa (NF-kB). Penghambatan tersebut menyebabkan adanya induksi apoptosis, penghambatan daur sel, dan penurunan ekspresi Bcl-XL sebagai downstream target dari NF-kB pada kultur sel kanker kandung kemih T24 dan HT1376, serta sel payudara MCF-7 dan MDAMB-231 (Hsu, Kuo, Tzeng, \& Lin, 2006).

NF-kB merupakan faktor transkripsi yang sangat berperan dalam pengembangan dan progresi kanker, karena NF-kB mengatur banyak gen yang terlibat dalam inflamasi, cell survival, proliferasi sel, invasi, angionegenis, dan metastasis (Sen \& Baltimore, 1986). Salah satu target dari $\mathrm{NF \kappa B}$ adalah Bcl-xL (pro-survival Bcl-2) yang merupakan regulator apoptosis (Pahl, 1999).

Arty et al. (2000) mensintesis beberapa senyawa derivat kalkon dengan gugus 
hidroksi pada posisi para. Hasil uji sitotoksik pada salah satu senyawa dengan struktur (3-(4'-hidroksi-3'-metoksifenil)-1-fenil-2propen-1-on) atau para hidroksi meta metoksi kalkon ( $p \mathrm{H} m \mathrm{MK}$ ) (Gambar 1) menunjukkan bahwa senyawa ini bersifat sitotoksik pada sel kanker HeLa, sel Raji (Arty, 2010), dan sel T47D, serta tidak memiliki aktivitas sitotoksik terhadap kultur sel normal Vero (Arianingrum, Arty, \& Atun, 2010)

Pada sel kanker payudara T47D, $p \mathrm{H} m \mathrm{MK}$ mampu menahan daur sel pada fase G2/M (Arianingrum, Sunarminingsih, Meiyanto, \& Mubarika, 2012). Sedangkan pada sel kanker payudara MCF-7, selain dapat menahan daur sel pada fase G2/M, senyawa ini juga mampu memacu terjadinya apoptosis (Arianingrum, Sunarminingsih, Meiyanto, \& Mubarika, 2015).
Apoptosis adalah kematian sel terprogram atau program bunuh diri yang memerlukan mRNA dan sintesis protein tertentu. Apoptosis merupakan suatu proses normal yang mempunyai dua fungsi, yaitu: perbaikan jaringan dan pelepasan sel yang rusak, yang dapat membahayakan tubuh (King, 2000). Apoptosis diperlukan oleh sel untuk menjaga homeostasis sebagai akibat serangan berbagai penyakit serta mencegah proliferasi yang tak terkontrol (Saraste \& Pulkki, 2000; Zimmermann, Bonzon, \& Green, 2001; Danial \& Korsmayer, 2004).

Salah satu karakter dari sel kanker adalah mampu menghindari mekanisme apoptosis. Resistensi terhadap apoptosis umumnya dihubungkan dengan tumorigenesis. Namun, sel tumor masih dapat diinduksi melalui mekanisme nonapoptotik seperti

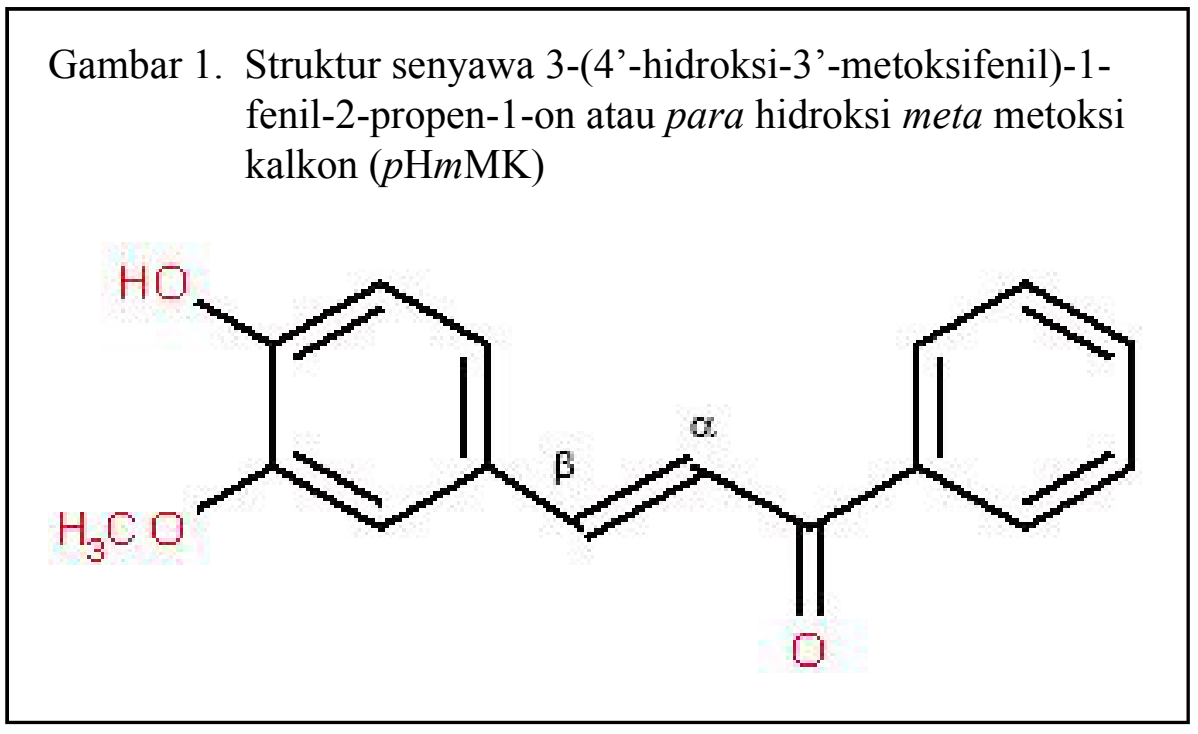


nekrosis dan mitotic catastrophe (Okada \& Mak, 2004; Brown \& Attardi, 2005). Hampir seluruh penelitian tentang terapi kanker difokuskan pada apoptosis karena merupakan proses gen-terkontrol sehingga lebih mudah dilakukan manipulasi genetik untuk tujuan terapi (Ferreira, Epping, Kruyt, \& Giaccone, 2002).

Mekanisme apoptosis dapat terjadi melalui dua jalur, yaitu melalui mitokondria (jalur intrinsik) dan melalui death receptor pada permukaan sel (jalur ekstrinsik) (Zimmermann et al., 2001; Kroemer \& Martin, 2005; Martin, 2006). Pada kedua jalur ini terjadi aktivasi cystein aspartylspesific protease (Caspase), yang memecah substrat seluler sehingga menyebabkan perubahan morfologi dan biokimia sel sebagai karakteristik apoptosis (Igney \& Krammer, 2002).

Proses utama apoptosis dikontrol oleh protein kelompok Bcl-2. Perubahan konformasi membran mitokondria tergantung pada rasio antara protein proapoptosis (Bax, Bad, Bak, Bid, dan Bcl-Xs) dengan protein anti-apoptosis (Bcl-2, BclXL, Bag-1, Bcl-W) (Fan, Han, Cong, \& Liang, 2005; Khan, Afag, \& Mukhtar, 2007; D'Archivio et al., 2008).

Penelitian ini bertujuan untuk mengkaji jalur mekanisme apoptosis dari senyawa $p \mathrm{H} m \mathrm{MK}$ pada sel payudara MCF7 dengan mengamati pengaruhnya terhadap ekspresi protein regulator apoptosis $\mathrm{Bcl}-2$ dan Bax.

\section{METODE PENELITIAN}

Pengamatan ekspresi protein Bcl-2 dan Bax dilakukan menggunakan metode imunositokimia dan analisis data dilakukan dengan menggunakan software ImageJ.

Peralatan yang digunakan adalah: plate 24 well, coverslip, mikroskop, eppendorft, pipet, dan tip. Bahan yang digunakan adalah metanol (Merck), etanol (Merck), PBS, akuades, hidrogen peroksida $\left(\mathrm{H}_{2} \mathrm{O}_{2}\right)$, antibodi monoklonal anti Bcl-2 dan Bax (Biocare), Starr Trek Universal HRP Detection Kit (Biocare), kromogen DAB, mayerhemaktoksilin (Dako), xylol, dan enteler.

Uji dilakukan dengan menanam sel (kepadatan $5 \times 10^{4} \quad$ sel/sumuran) ditanam pada coverslips dalam plate 24 sampai $80 \%$ konfluen. Setelah itu diinkubasi dengan senyawa uji selama 24 jam. Medium diambil, dicuci dengan PBS 2 kali. Selanjutnya sel dalam coverslips difiksasi dengan metanol dingin dan dicuci PBS 2 kali, kemudian dicuci dengan akuades 2 kali. Coverslips dipindahkan dalam slide kemudian ditambahkan $300 \quad \mathrm{~mL}_{2} \quad \mathrm{H}_{2} \mathrm{O}_{2} \quad(1: 9$ dalam akuades), kemudian diinkubasi selama 10 menit, dibuang dan dicuci dengan PBS 2 kali. Selanjutnya ditambahkan $100 \mathrm{~mL}$ Blocking (Background Snipper), inkubasi selama 15 menit pada suhu kamar, dibuang dan 
ditambahkan $50 \mathrm{~mL}$ antibodi primer (Bcl-2 atau Bax) inkubasi selama 60 menit. Setelah dibuang dicuci dengan PBS 2 kali, kemudian tambahkan $100 \mathrm{~mL}$ antibodi sekunder(Trekkie Universal) inkubasi selama 20 menit pada suhu kamar. Setelah dibuang, dicuci dengan PBS 2 kali dan ditambahkan Trek Avidin$H R P$, diinkubasi selama 10 menit pada suhu kamar, dibuang dan dicuci dengan PBS 2 kali. Dilanjutkan dengan penambahan 100 mL DAB, diinkubasi 5 menit, dibuang, dan dicuci dengan akuades. Setelah dibuang dan dibersihkan dengan tisu ditambahkan dengan $300 \mathrm{~mL}$ mayer-hemaktoksilin dan diinkubasi 5 menit. Kemudian dicuci dengan akuades hingga bersih. Slide (preparat) dicelup dalam etanol, kemudian dicelup dalam xylol. Setelah kering ditutup dengan cover glass dan ditambahkan enteler. Ekspresi protein diamati menggunakan mikroskop. Sel yang mengekspresikan protein tertentu akan memberikan warna coklat/gelap, sedangkan yang tidak mengekspresikan protein tertentu memberikan warna biru/ungu.

\section{HASIL DAN PEMBAHASAN}

Pengamatan ekspresi protein $\mathrm{Bcl}-2$ dan Bax pada sel MCF-7 dilakukan dengan membandingkan ekspresi protein Bcl-2 dan Bax tanpa perlakuan $p \mathrm{H} m \mathrm{MK}$ (sebagai kontrol) dan dengan perlakuan $p \mathrm{H} m \mathrm{MK}$. Pada penelitian ini perlakuan $\mathrm{pHmMK}$ dilakukan di bawah konsentrasi $\mathrm{IC}_{50}(40$
$\mathrm{mM}$ ), yaitu sebesar 10 dan $20 \mathrm{mM} . \mathrm{IC}_{50}$ (50\% inhibition concentration) yaitu konsentrasi sampel yang menghambat sel sebesar $50 \%$.

\section{Ekspresi Bcl-2}

Salah satu karakteristik dari sel MCF7 adalah overekspresi Bcl-2 (Butt, Firth, King, \& Baxter, 2000; Amundson et al., 2000). Hasil pemeriksaan imunositokimia menunjukkan adanya penurunan ekspresi protein Bcl-2 pada sel MCF-7 setelah perlakuan dengan $p \mathrm{H} m \mathrm{MK}$ dibandingkan dengan tanpa perlakuan (Gambar 2). Ekspresi Bcl-2 ditunjukkan dengan adanya ikatan antara protein Bcl-2 dengan antibodi monoklonal anti Bcl-2 yang terdeteksi berupa warna coklat pada sitoplasma dan membran sel MCF-7. Ekspresi Bcl-2 semakin menurun dengan semakin meningkatnya konsentrasi $p \mathrm{H} m \mathrm{MK}$.

Analisis data dengan software ImageJ dilakukan untuk menghitung ekspresi protein Bcl-2 secara semi kuantitatif dengan menghitung jumlah pixel threshold (area) serta persentase pixel threshold (\% area) per satu lapang pandang. Hasil analisis melalui image quantification dari rerata 5 (lima) lapang pandang (Gambar 3) menunjukkan bahwa ekspresi Bcl-2 pada sel tanpa perlakuan sebesar 4,805\% dari area lapang pandang, sedangkan ekspresi Bcl-2 dengan perlakuan $\mathrm{pHm} M K$ sebesar 10 dan $20 \mathrm{mM}$ 
Gambar 2. Efek Perlakuan pHmMK terhadap Ekspresi Bcl-2 pada Sel MCF-7 Sel MCF-7 ditanam sebanyak $5 \times 10^{4} \mathrm{sel} / \mathrm{sumuran}$ pada coverslips dalam plate 24 well. Setelah diinkubasi 24 jam, selanjutnya diberi perlakuan sampel serta sampel tanpa uji. (A). Kontrol sel tanpa perlakuan sampel yang tidak dicat dengan antibodi, (B) Kontrol sel (tanpa perlakuan sampel yang dicat dengan antibodi), (C) Perlakuan $p \mathrm{H} m \mathrm{MK} 10 \mathrm{mM}$, (D) Perlakuan $p \mathrm{H} m \mathrm{MK} 20 \mathrm{mM}$. Pengamatan di bawah mikroskop cahaya perbesaran 400x (Bcl-2 positif à, Bcl-2 negatif - ->)

A

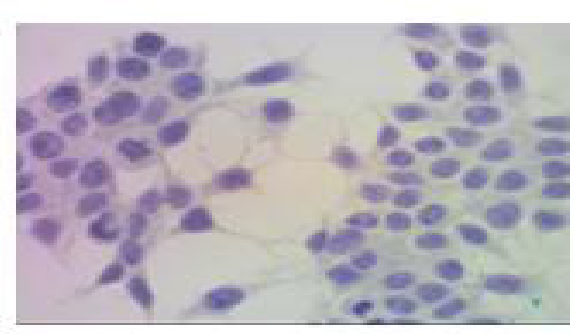

C

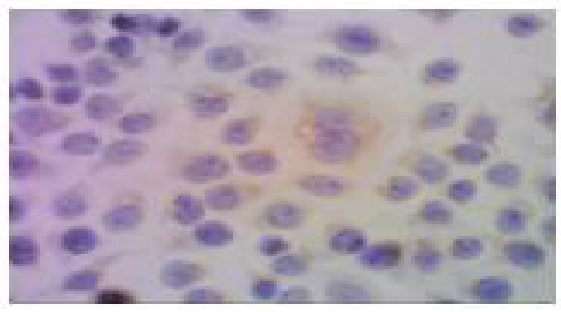

B

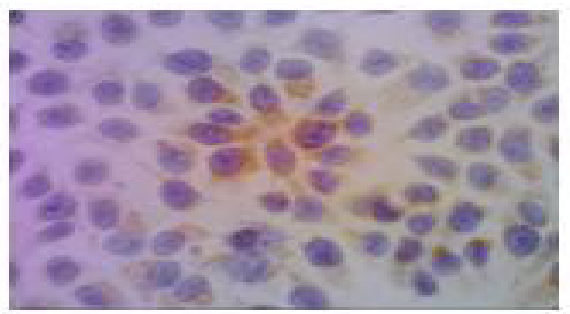

$\mathrm{D}$

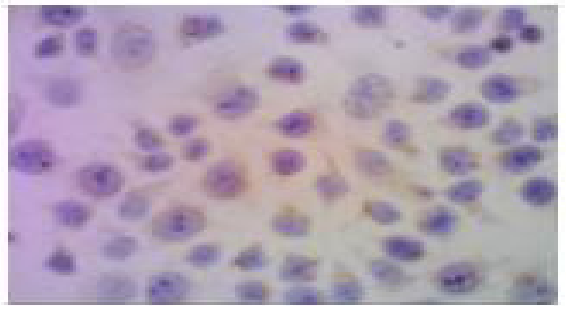

Gambar 3. Hasil analisis ekspresi protein Bcl-2 pada sel MCF-7 tanpa perlakuan $p \mathrm{H} m \mathrm{MK}$ (kontrol sel) dan dengan perlakuan $p \mathrm{H} m \mathrm{MK} 10 \mathrm{mM}$ dan 20 $\mathrm{mM}$ secara semikuantitatif dengan software imageJ

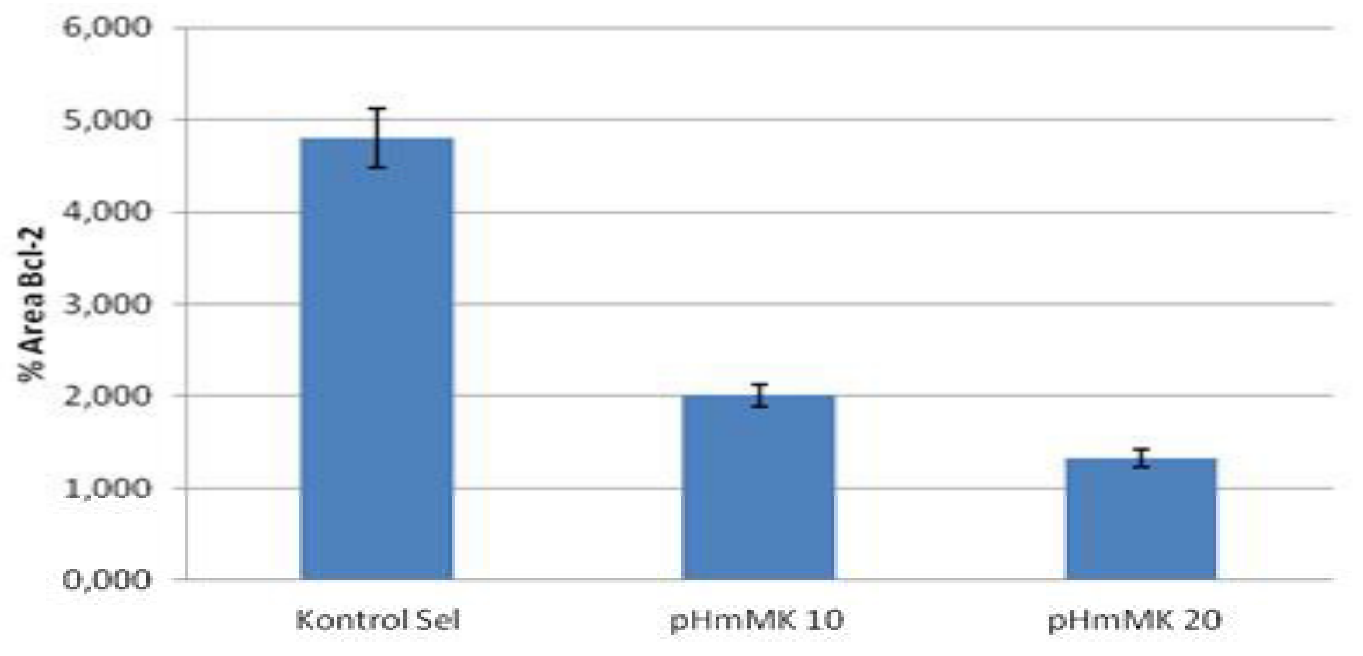


berturut-turut sebesar $2,008 \%$ dan $1,324 \%$. Hasil ini menggambarkan adanya penurunan ekspresi Bcl-2 sebesar 58\% setelah perlakuan pHmMK $10 \mathrm{mM}$, dan penurunan sebesar $72 \%$ setelah perlakuan $p H \mathrm{~m} M K 20 \mathrm{mM}$.

\section{Ekspresi Bax}

Hasil pengamatan imunositokimia menunjukkan adanya kenaikan ekspresi Bax pada sel MCF-7 setelah perlakuan dengan $p \mathrm{H} m \mathrm{MK}$ (Gambar 4). Ekspresi Bax semakin meningkat dengan meningkatnya konsentrasi $p \mathrm{H} m \mathrm{MK}$ yang terdeteksi berupa warna coklat pada sitoplasma sel MCF-7.

Hasil analisis melalui image quantification dari rerata 5 (lima) lapang pandang (Gambar 5) menunjukkan bahwa ekspresi Bax pada sel MCF-7 tanpa perlakuan sebesar $0,388 \%$ dari area lapang pandang, sedangkan ekspresi Bax dengan perlakuan pHmMK sebesar 10 dan $20 \mathrm{mM}$ berturutturut sebesar 2,942\% dan 5,229\%. Hasil ini menggambarkan kenaikan ekspresi Bax sebesar lebih dari 7 kali setelah perlakuan pHmMK $10 \mathrm{mM}$, dan kenaikan lebih dari 13 kali setelah perlakuan $p H \mathrm{~m} M K 20 \mathrm{mM}$.

Gambar 4. Efek perlakuan $p \mathrm{H} m \mathrm{MK}$ terhadap ekspresi Bax pada sel MCF-7 Sel MCF-7 ditanam sebanyak $5 \times 10^{4} \mathrm{sel} /$ sumuran pada coverslips dalam plate 24 well. Setelah diinkubasi 24 jam, selanjutnya diberi perlakuan sampel serta sampel tanpa uji. (A). Kontrol sel tanpa perlakuan sampel yang tidak dicat dengan antibodi, (B) Kontrol sel (tanpa perlakuan sampel yang dicat dengan antibodi), (C) Perlakuan $p \mathrm{H} m \mathrm{MK} 10 \mathrm{mM}$, (D) Perlakuan $p \mathrm{HmMK} 20 \mathrm{mM}$. Pengamatan di bawah mikroskop cahaya perbesaran 400x (Bax positif à, Bax negatif - ->)

A

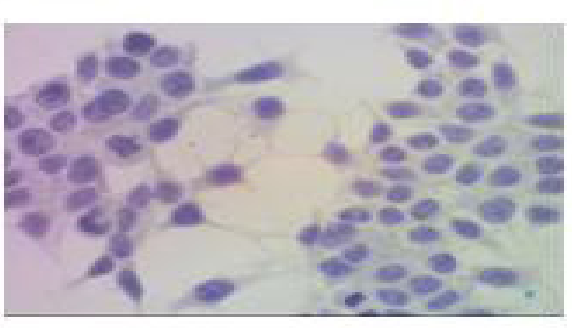

C

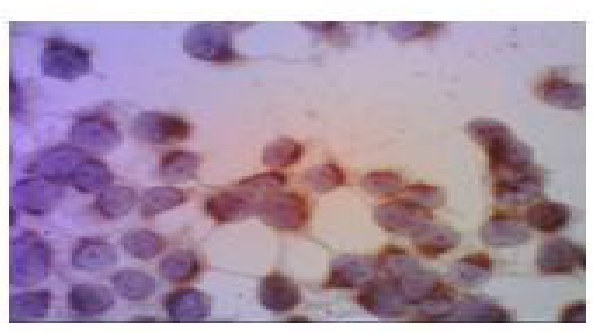

B

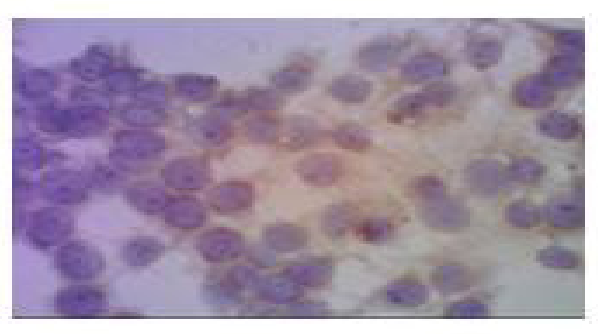

D

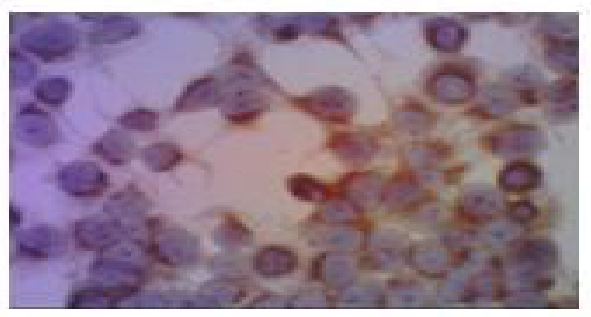




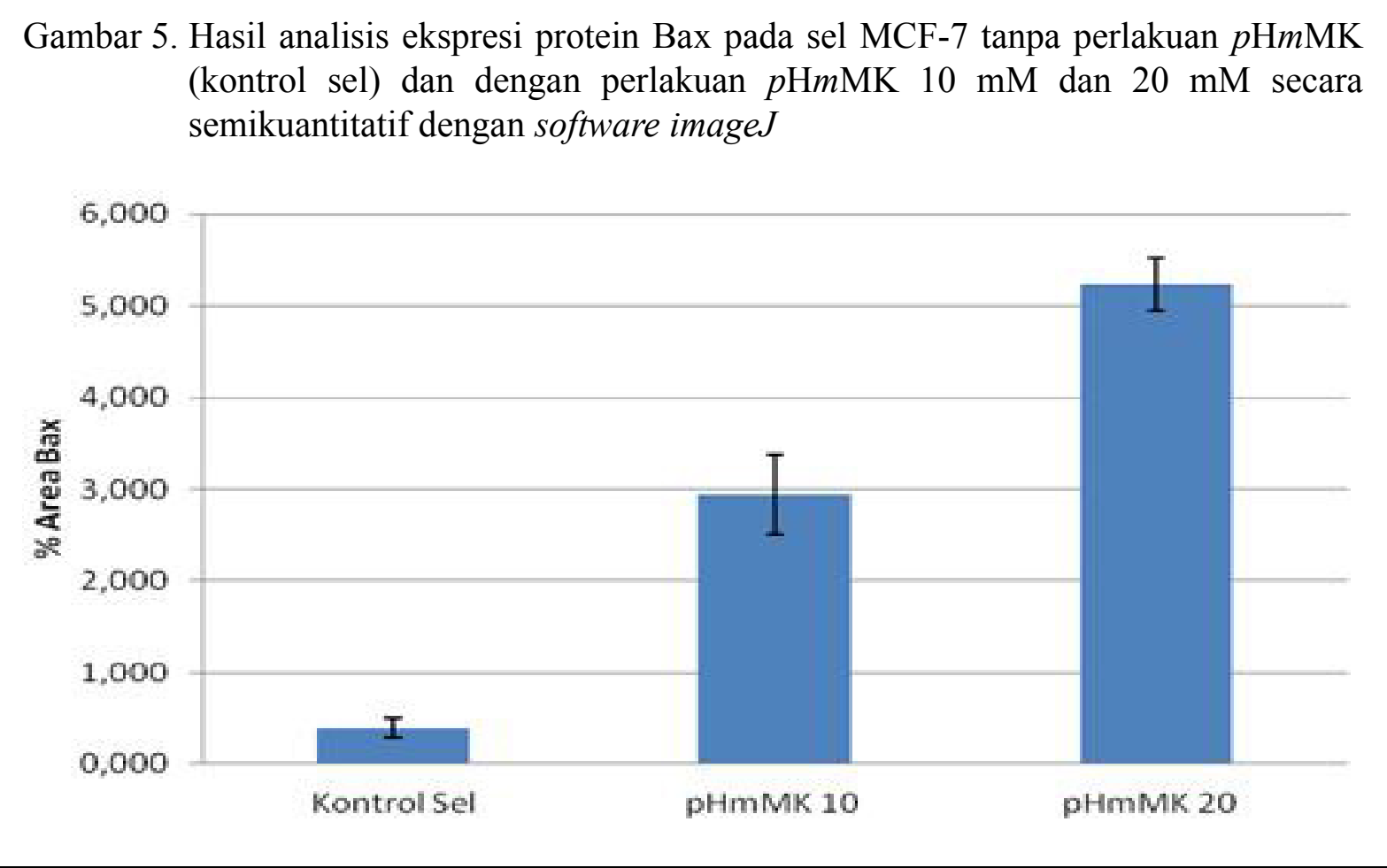

Melalui penelitian ini menunjukkan bahwa $p \mathrm{H} m \mathrm{MK}$ dapat menurunkan ekspresi Bcl-2 dan meningkatkan ekspresi Bax. Protein Bcl-2 merupakan protein antiapoptotik, sedangkan protein Bax bersifat proapoptotik. Protein-protein tersebut berperan dalam regulasi apoptosis melalui pengaturan pelepasan Cytc (sitokrom). Igney dan Krammer (2002) menyatakan bahwa ekspresi Bcl-2 mencegah pelepasan Cyt c dari mitokondria. Bax akan menginduksi pelepasan Cyt c. Di dalam sitosol Cyt C akan membentuk komplek dengan Apaf-1 (Apoptotif Protease Activating Factor-1), ATP dan Procaspase-9. Komplek ini disebut apoptosom, yang mengaktifkan caspase-9.
Caspase-9 meng-aktivasi caspase 6 dan caspase-7 untuk mengeksekusi apoptosis.

Dengan demikian penelitian ini menunjukkan bahwa mekanisme apoptosis dari $p \mathrm{H} m \mathrm{MK}$ adalah melalui jalur mitokondria dengan meningkatkan rasio $\mathrm{Bax} / \mathrm{Bcl}-2$. Pada penelitian ini rasio Bax/Bcl2 dari 0,08 menjadi 1,47 setelah perlakuan pHmMK 10 mM; dan menjadi 3,95 setelah perlakuan $p$ HmMK $20 \mathrm{mM}$. Pada rasio ini ternyata mampu mengganggu potensial membran mitokondria sehingga terjadi pelepasan Cyt c ke sitosol. Bagaimana pengaruhnya terhadap ekspresi caspase-9, caspase-6 dan caspase-7 perlu dilakukan penelitian lebih lanjut. 
Kemampuan $p \mathrm{H} m \mathrm{MK}$ dalam memacu apoptosis berkaitan erat dengan strukturnya. Senyawa $p \mathrm{H} m \mathrm{MK}$ merupakan derivat kalkon dengan gugus hidroksi $(\mathrm{OH})$ pada posisi para dan gugus metoksi $\left(\mathrm{OCH}_{3}\right)$ pada posisi meta. Senyawa ini juga mengandung ikatan tak jenuh a, b. Srinivasan, Johnson, Lad, \& Xing (2009) menyatakan bahwa ikatan tak jenuh a, b pada kalkon bersifat sangat elektrofilik, sehingga dapat meningkatkan radikal-radikal yang menyebabkan reduksi alkena melalui adisi Michaelis dari nukleofil, seperti SH pada cystin yang terdapat pada DNA, yang mengikat NF-kB. Hal ini menyebabkan penghambatan aktivasi NFkB yang selanjutnya berdampak menurunkan ekspresi Bcl-xL sebagai downstream target dari NF-kB. Bcl-xL yang merupakan prosurvival Bcl-2.

Penelitian ini juga sejalan dengan hasil Hsu et al. (2006) yang menunjukkan bahwa struktur dasar kalkon (1,3-difenilpropen1-on) dapat menghambat proliferasi sel kanker payudara MCF-7 dan MDA-MB-231 dengan menginduksi apoptosis, yaitu dengan meningkatkan Bax dan Bak serta menurunkan ekspresi Bcl-2 dan Bcl-xL. Adanya gugus $\mathrm{OH}$ dan metoksi pada $p \mathrm{H} m \mathrm{MK}$ tentunya juga akan mempengaruhi penghambatan aktivitas NFkB. Namun masih diperlukan penelitian yang lebih mendalam, karena pada penelitian ini tidak dilakukan perbandingan aktivitasnya dengan senyawa kalkon.

\section{SIMPULAN}

Berdasarkan penelitian di atas dapat diambil kesimpuan bahwa mekanisme pemacuan apoptosis oleh $p \mathrm{H} m \mathrm{MK}$ dengan menurunkan ekspresi Bcl-2 dan meningkatkan ekspresi Bax.

\section{DAFTAR PUSTAKA}

Amundson, S. A., Myers, T. G., Scudiero, D., Kitada, S., Reed, J. C., \& Fornace, A. J. (2000). An informatics approach identifying markers of chemosensitivity in human cancer cell lines. Cancer Res, 60, 6101-6110.

Arianingrum, R., Arty, I. S., \& Atun, S. (2010). Uji sitotoksisitas senyawa mono para hidroksi kalkon terhadap cancer cell lines T47D. Saintek, 16(2), 121 -132.

Arianingrum, R., Sunarminingsih, R., Meiyanto, E., \& Mubarika, S. (2012, June). Potential of a chalcone derivate compound as cancer chemoprevention in breast cancer. Dalam Proceedings of the $20123^{\text {rd }}$ International Conferen-ce on Chemistry and Chemical Engineering IPCBEE, Singapore (pp. 29-30).

Arianingrum, R., Sunarminingsih R., Meiyanto, E., \& Mubarika, S. (2015, May). Cytotoxic effect of para hydroxy meta methoxy chalcone $(p \mathrm{H} m \mathrm{MC})$ on MCF-7 breast cancer cells by inducing cell arrest and apoptosis. Dalam Proceedings of International Conference on Research, Implementation and Education of Mathematics and Sciences 2015 (pp. C-89-C95). Yogyakarta State University. 
Arty, I. S. (2010). Synthesize and citotoxicity test of several compounds of mono para-hidroxy chalcone. Indo. J. Chem. 10(1), 110-115.

Arty, I. S., Timmerman, H., Samhoedi, M., Sastrohamidjojo, Sugiyanto, \& van der Goot, H. (2000). Synthesis of benzylideneacetophenones and their inhibition of lipid peroxidation. European Journal of Medicinal Chemistry, 35(4), 449-457.

Boumendjel, A., Ronot, X., \& Boutonnat, J. (2009). Chalcones derivatives acting as cell cycle blockers: potential anti cancer drugs? Current drug targets, 10(4), 363-371.

Brown, M., \& Attardi, L. D. (2005). The role of apoptosis in cancer development and treatmen response. Nature Rev. Cancer, 5, 231-236.

Butt, A. J., Firth, S. M., King, M. A., \& Baxter, R. C. (2000). Insulin-like growth factor-binding protein-3 modulates expression of bax and bcl2 and potentiates P53-independent radiation-induced apoptosis in human breast cancer cells. J. Biol Chem, 275(50), 39174-39181.

D'Archivio, M., Santangelo, C., Scazzochio, B., Vari, R., Filesi, C., Massela, R., \& Giovannini, C. (2008). Modulatory effect of polyphenol on apoptosis induction relevance for cancer prevention. Int. J. Mol. Sci, 9, 213-228.

Danial, N. N., \& Korsmeyer, S.J. 2004. Cell Death: Critical Control points. Cell, 116, 205-219.
Davis, J. M., Navolanic, P. M., WeinsteinOppenheimer, C. R., Steelman, L.S ., Wei, H., Konopleva, M., Blagosklonny, M. V., \& McCubrey, J. A. (2003). Raf-1 and $\mathrm{Bcl}-2$ Induce distinc and common pathways that contribute to breast cancer drug resistantce. Clin. Cancer Res., 9, 1161-1170.

Fan, T-J., Han, L-H, Cong, R-S., \& Liang. J. (2005). Caspase family proteases and apoptosis. Acta Biochim. Biophys. Sin., 37(11), 719-727.

Ferreira, G. C., Epping, M., Kruyt, F. A. E., \& Giaccone, G. (2002). Apoptosis: Target of cancer therapy. Clin. Cancer Research, 8, 2024-2034.

Hsu, Y. L., Kuo, P. L., Tzeng, W. W., \& Lin, C. C. (2006). Chalcone Inhibits the proliferation of human breast cancer cell by blocking cell cycle progression and inducing apoptosis. Food Chem Toxicol, 44(5), 704-713.

Igney, F. H., \& Krammer, P. H. (2002). Review: Death and anti-death: Tumor Resistance to Apoptosis. Nature Review: Cancer, 2, 277-286.

Khan, N., Afag, F., \& Mukhtar, H. (2007). Apoptosis by dietary factors: The suicide solution for delaying cancer growth. Carcinogenesis, 88(2), 233-239.

King, R. J. B. (2000). Cancer biology (2 $2^{\text {nd }}$ ed.). England: Pearson Education.

Kroemmer, G., \& Martin, S. J. (2005). Caspase-independent cell death. Nature Med., 11(7), 725-730. 
Martin, K. R. (2006). Targeting apoptosis with dietary bioactive agents. Exp. Biol. Med., 231, 117-129.

Okada, H., \& Mak, T. W. (2004). Pathway of Apoptotic and non-apoptotic death in tumour cells. Nature Rev. Cancer, 4, 592-603.

Pahl, H. L.. (1999). Activators and Target genes of $\mathrm{rel} / \mathrm{NF}-\mathrm{\kappa B}$ transcription factors. Oncogene, 18, 6853-6866.

Saraste, A., \& Pulkki, K. (2000). Morphologic and biochemical hallmarks of apoptosis. Cardiovascular Research, 45, 528-537.

Sen, R., \& Baltimore, D. (1986). Inducibility of kappa immunoglobulin enhancerbinding protein Nf-kappa B by a posttranslational mechanism. Cell, 47, 921-928.

Shah, A., Khan, A. M., Qureshi, R., Ansari, F. L., Nazar, M. F., \& Shah, S. S. (2008). Redox behavior of anticancer chalcone on a glassy carbon electrode and evaluation of its interaction parameters with DNA. International journal of molecular sciences, 9(8), 1424-1434.

Shen, K. H., Chang, J. K., Hsu, Y. L., \& Kuo, P. L. (2007). Chalcone arrests cell cycle progression and induces apoptosis through induction of mitochondrial pathway and inhibition of nuclear factor kappa B signalling in human bladder cancer cells. Basic \& clinical pharmacology \& toxicology, 101(4), 254-261.

Srinivasan B., Johnson T.E., Lad R., Xing C. (2009). Structure-activity relationship studies of chalcone leading to 3-hydroxy-4,3', $4^{\prime}, 5^{\prime}$ tetramethoxychalcone and its analogues as potent nuclear factor kappaB inhibitors and their anticancer activities. J Med Chem., 52, 72287235.

Tjindarbumi, D., \& Mangunkusumo, R. (2002). Cancer in Indonesia, present and future. Jpn. J. Clin. Oncol., 32 (Supplement 1), S17-21.

WHO. (2006). Cancer control, knowlendge into action. WHO Guide for Effective Programes, diunduh dari http://www. who.int/cancer.

Wong, H. L., Bendayan, R., Rauth, A. M., Xue, H. Y., Babakhanian, K., \& Wu, X. Y. (2006). A mechanistic study of enhanced doxorubicin uptake and retention in multidrug resistant breast cancer cells using a polymer-lipid hybrid nanoparticle system. The Journal of Pharmacology and Experimental Therapeutics, 317(3), 1372-1381.

Zimmerman, K. C., Bonzon, C., \&Green, R.D. (2001). The machinery of programmed cell death. Pharmacology and Therapeutics, 92, 57-70. 